\title{
PEMBERDAYAAN MASYARAKAT MELALUI PELATIHAN PEMBUATAN KERAJINAN DARI BARANG BEKAS DI DESA BAHARI
}

Nastia ${ }^{1)}$, Nurlinda ${ }^{2)}$, Meri Meliyanti Saputri ${ }^{3)}$, Nursalim ${ }^{4)}$

${ }^{1}$ Dosen Program Studi Ilmu Pemerintahan, Fakultas Ilmu Sosial dan Ilmu Politik

${ }^{2,3,4}$ Mahasiswa Program Studi Ilmu Pemerintahan, Fakultas Ilmu Sosial dan Ilmu Politik

Universitas Muhammadiyah Buton

Email: nastiatia567@gmail.com

\begin{abstract}
Abstrak
Program pengabdian masyarakat ini dilakukan di Desa Bahari Kecamatan Sampolawa Kabupaten Buton Selatan. Program pengabdian masyarakat ini menyimpulkan bahwa dari kegiatan ini memberikan keterampilan membuat kerajinan dengan bahan baku limbah rumah tangga, mendistribusikan atau memasarkan hasil kerajinan. Metode yang digunakan adalah pendampingan, pelatihan, dan praktek langsung. Capaian pelatihan adalah peserta pemberdayaan memiliki keterampilan dalam mengolah sampah plastik dan botol bekas sehingga memiliki nilai yang lebih ekonomis. Selain itu peserta pemberdayaan memiliki kreativitas yang tinggi dalam menciptakan produk yang lebih variasi.
\end{abstract}

Kata Kunci : Pemberdayaan Masyarakat, Pelatihan Pembuatan Kerajinan, Barang Bekas 


\section{PENDAHULUAN}

Pemberdayaan memiliki makna kesetaraan, adil, dan demokratis tanpa adanya tekanan atau dominasi dalam suatu komunitas atau masyarakat. Namun, dalam praktiknya program-program pemberdayaan yang ada sering kali mengalami permasalahan, salah satunya yaitu tidak meratanya program pemberdayaan yang diterima oleh masyarakat (Hidayat et al., 2018). Pemberdayaan masyarakat merupakan suatu usaha sadar untuk meningkatkan kesejahteraan masyarakat. melihat pengertian mengenai pemberdayaan, pada intinya membahas bagaimana individu, kelompok, ataupun komunitas berusaha mengontrol kehidupan mereka sendiri dan mengusahakan untuk bentuk masa depan sesuai dengan keinginan mereka (Isbandi Rukminto Adi, 2008).

Pemberdayaan masyarakat adalah suatu proses dimana masyarakat, khususnya mereka yang kurang memiliki akses kesumber daya pembangunan, didorong untuk meningkatkan kemandiriannya mengembangkan perikehidupan mereka sendiri. Pemberdayaan masyarakat juga merupakan proses siklus terus menerus, proses partisipatif dimana anggota masyarakat bekerja sama dalam kelompok formal maupun informal untuk berbagi pengetahuan dan pengalaman serta berusaha mencapai tujuan bersama (Moh. Ali Aziz, dkk, 2005). Jadi, pemberdayaan masyarakat lebih merupakan suatu proses.

Pemberdayaan masyarakat dapat dilakukan melalui perbaikan lingkungan tempat tinggal dan pengembangan usaha ekonomi desa, serta beberapa kegiatan lainnya yang tujuannya untuk meningkatkan kesejahteraan masyarakat. Dalam upaya pemberdayaan masyarakat tidak harus selalu membicarakan tentang kesejahteraan, tetapi dalam prosesnya juga perlu disisipkan nilai-nilai seperti kerja keras, hemat, keterbukaan, serta selalu berpikir kreatif dan inovatif.

Pemberdayaan masyarakat salah satunya yaitu adalah mengenai pemberdayaan perempuan, dimana dalam era globalisasi yang semakin maju menuntut adanya perubahan besar yang berkaitan dengan pemberdayaan perempuan. Pemberdayaan perempuan dapat menjembatani kesetaraan antara kaum laki-laki dan perempuan dalam kehidupan bermasyarakat, berbangsa, dan bernegara. Berbagai peran yang ada di masyarakat seharusnya dapat terlepas dari adanya diskriminasi, perbedaan antara hak lakilaki dan perempuan. Sehingga laki-laki dan perempuan memiliki peluang dan kesempatan yang sama dalam mengapresiasi kewajiban dan hak-haknya.

Pada umumnya kelompok masyarakat mengharapkan lingkungan tempat tinggal yang bersih, rapi, teratur, dan bebas dari sampah. Kondisi ini tidak akan tercipta begitu saja apabila tidak diusahakan, apalagi mengenai sampah yang oleh sebagian orang masih enggan untuk mengolahnya, karena dianggap tidak berguna dan kotor.

Berbagai macam sampah dihasilkan oleh kegiatan manusia atau masyarakat. Sampah yang dihasilkan macam-macam, mulai dari sampah kertas, cair, maupun plastik. Namun, sampah yang paling banyak ditemui dan masih 
sulit penanganannya yaitu sampah plastic karena tidak dapat diurai dengan mudah dan memerlukan penanganan khusus, biasanya sebagai alternatif dapat dimanfaatkan kembali dengan mengolahnya menjadi suatu kerajinan maupun suatu bentuk yang mempunyai nilai jual lainnya.

Melalui pelatihan, diharapkan perempuan mampu diberdayakan dengan lebih cepat dan efektif karena pemberdayaan melalui pelatihan bisa dilakukan dengan waktu yang relatif singkat dan tetap menekankan pada proses sehingga kemampuan untuk berdaya pun bisa lebih mudah. Peranan strategis perempuan dalam menyukseskan pembangunan bangsa tersebut salah satunya dapat dilakukan melalui peranan perempuan dalam keluarga. Perempuan merupakan benteng utama dalam keluarga peningkatan kualitas sumber daya manusia dimulai dari peran perempuan.

Kegiatan PKM ini dilaksanakan oleh dosen dan mahasiwa Program Studi Ilmu Pemerintahan Fakultas Ilmu Sosial dan Ilmu Politik Universitas Muhammadiyah Buton. Kegiatan pengabdian ini tidak hanya sebagai perwujudan tanggung jawab dosen dalam hal tridharma perguruan tinggi yang dilaksanakan rutin setiap tahun pada masyarakat, melainkan juga sebagai sebuah kegiatan yang memberikan pengalaman kepada mahasiswa untuk belajar dan menerapkan keterampilan sesuai bidang keahlian yang di pelajari untuk di terapkan kepada masyarakat. Kegiatan ini tentunya akan menambah wawasan sekaligus melengkapi keterampilan dosen dan mahasiswa.

Masalah yang dihadapi mitra adalah kurangnya wawasan dan kesadaran masyarakat terhadap sampah. Kegiatan pengabdian kepada masyarakat (PKM) ini diselenggarakan di Desa Bahari Kecamatan Sampolawa Kabupaten Buton Selatan. Adapun tujuan dari pengabadian masyarakat dilaksanakan ialah untuk memberikan pendampingan pembinaan melalui pelatihan pembuatan kerajinan dari barang bekas. Output yang menjadi target dalam pengabdian ini adalah masyarakat khusunya perempuan di desa Bahari mempunyai keterampilan dalam mengelolaan pembuatan kerajinan dari barang bekas.

\section{METODE PENELITIAN}

Untuk mengatasi permasalahan sampah plastik yang berada di Desa Bahari, maka tim PKM akan diberikan pelatihan untuk mengolah sampah plastik menjadi bahan konsumtif yang memiliki nilai jual dan kualitas baik serta ekonomis.

Pelaksanaan pengabdian ini dengan menggunakan metode pelatihan terlebih dahulu, pelatihan dilakukan dengan bersamasama. Pelatihan dipandu oleh beberapa mentor. Setelah pelatihan selesai kemudian praktik secara langsung dalam pembuatan kerajinan dari bahan bekas tersebut.

Kerajinan yang sudah jadi nantinya akan diberi warna dengan cara mengecat kerajinan tersebut. Setelah dilakukan pengecatan, produk itu dipasarkan di daerah wisata Pantai Bahari. Harapannya dengan memasarkan hasil kerajinan masyarakat yang telah dibuat oleh perempuan di Desa Bahari, maka akan menjadikan wisata Pantai Bahari semakin 
banyak dikunjungi oleh wisatawan baik dari domestik maupun mancanegara. Selain itu kerajinan akan banyak dikenal oleh orang lain sehingga bisa juga dilakukan pemesanan untuk kerajinan tersebut sehingga bisa dikenal oleh banyak orang. Harapannya kerajinan yang dibuat bisa digunakan untuk souvenir serta hiasan di rumah mampu untuk digunakan sendiri. Selain itu kerajinan itu bisa memberikan pemasukan tambahan untuk keluarga, secara luas untuk semua masyarakat sehingga bisa membuat Usaha Kecil Menengah. Kerajinan itu diharapkan juga bisa menjadi ikon di kawasan Pantai Bahari.

\section{HASIL DAN PEMBAHASAN}

Di Desa Bahari Potensi objek wisata memiliki daya tarik yang hingga saat ini belum dikembangkan. Potensi wisata di Desa Bahari secara garis besar adalah wisata alam. Dengan dikelolanya objek wisata di Desa Bahari ini akan mendorong laju perekonomian rakyat, karena dengan adanya tujuan wisata di Desa ini akan mampu mempromosikan semua sektor sektor ekonomi yang ada di desa, baik itu dari kerajinan, pertaanian, dan budaya.
Hasil pelatihan pemberdayaan masyarakat memiliki keterampilan dalam mengolah sampah plastik dan botol bekas sehingga memiliki nilai yang lebih ekonomis. Selain itu masyarakat memiliki kreativitas yang tinggi dalam menciptakan produk yang lebih variasi serta dapat di perdaganggkan pada lokasi objek wisata pantai bahari.

Peserta kegiatan Pemberdayaan Masyarakat Melalui Pelatihan Pembuatan Kerajinan dari Barang Bekas di Desa Bahari adalah perempuan berusia 15-59 tahun. Meningkatkan keberdayaan penduduk usia 15-59 tahun melalui peningkatan pengetahuan, sikap, dan keterampilan serta berusaha secara mandiri.

$$
\text { Hasil kegiatan Pemberdayaan }
$$

Masyarakat Melalui Pelatihan Pembuatan Kerajinan Dari Barang Bekas di Desa Bahari adalah:

1. Masyarakat (perempuan) memiliki keterampilan dalam mengolah sampah plastik terutama botol bekas.

2. Masyarakat (perempuan) memiliki kreatifitas dalam membentuk model kerajinan yang lebih variatif.

Tabel 1. Tahapan Kegiatan Pengabdian

\begin{tabular}{|c|l|l|l|}
\hline No & Tahapan Kegiatan & $\begin{array}{l}\text { Metode yang } \\
\text { Digunakan }\end{array}$ & Keterangan \\
\hline 1. & Survei dan Penetapan Wilayah Mitra & $\begin{array}{l}\text { Pertemuan dan } \\
\text { diskusi }\end{array}$ & Tim PKM dan Kepala Desa, \\
\hline 2. & $\begin{array}{l}\text { Pelaksanaan Kegiatan Penyampaian } \\
\text { Materi Pemberdayaan Masyarakat Melalui } \\
\text { Pelatihan Pembuatan Kerajinan Dari } \\
\text { Barang Bekas di Desa Bahari }\end{array}$ & $\begin{array}{l}\text { Pertemuan, } \\
\text { Ceramah } \\
\text { diskusi dan }\end{array}$ & $\begin{array}{l}\text { Tim PKM, Aparatur Perangkat } \\
\text { desa Kepala Dusun dan } \\
\text { Masyarakat (perempuan) desa } \\
\text { bahari perangkat } \\
\text { Kerajinan }\end{array}$ \\
\hline 3. & $\begin{array}{l}\text { Pelatihan dan Pendampingan Pembuatan } \\
\text { desa }\end{array}$ \\
\hline
\end{tabular}


Proses pelaksanaankegiatanyang telah dilakukan dalam Pemberdayaan Masyarakat Melalui Pelatihan Pembuatan Kerajinan Dari Barang Bekas di Desa Bahari memberikan pendidikan kreativitas usaha mandiri untuk meningkatkan kemampuan atau keterampilan dasar usaha yang dilatihkan melalui pembelajaran produktif dan keterampilan bermata pencaharian yang dapat meningkatkan penghasilan, baik secara perorangan maupun kelompok sebagai salah satu upaya penguatan keterampilan sekaligus pengentasan kemiskinan.

Uraian hasil kegiatan Pemberdayaan Masyarakat Melalui Pelatihan Pembuatan Kerajinan Dari Barang Bekas di Desa Bahari yang dilaksanakan dijelaskan dalam sub bab selanjutnya.

\section{Sosialisasi}

Kegiatan "Sosialisasi dalam Pemberdayaan Masyarakat Melalui Pelatihan Pembuatan Kerajinan Dari Barang Bekas" sangat penting karena kerajinan dari barang bekas pada umumnya masih asing bagi sebagian masyarakat yang berada pada kawasan atau daerah tertinggal dan terbelakang atau daerah terpencil. Sosialisasi dimaksudkan untuk memperkenalkan kerajinan dari barang bekas kepada masyarakat. Khusus kepada Warga disosialisasikan bagaimana bentuk kegiatannya, cara pelaksaaannya, siapa yang melaksanakan, berapa lama berlangsung, apa saja yang menjadi hak dan kewajiban warga dalam mengikuti kegiatan ini. Sosialisasi dilaksanakan beberapa kali, agar kegiatan "Pemberdayaan Masyarakat Melalui Pelatihan Pembuatan Kerajinan Dari Barang Bekas di Desa Bahari" dapat dipahami dan dimengerti oleh masyarakat sebagai sasaran. Selain itu, agar kegiatan ini mendapat dukungan dari pemerintah setempat.

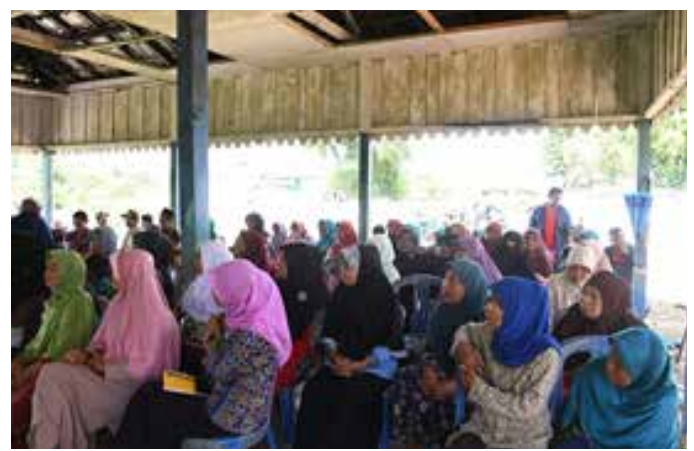

Gambar 1. Sosialisasi PKM Tentang Pemberdayaan Masyarakat Melalui Pelatihan Pembuatan Kerajinan Dari Barang Bekas di Desa Bahari

\section{Pelaksanaan Kegiatan}

Dalam melaksanakan kegiatan "Pemberdayaan Masyarakat Melalui Pelatihan Pembuatan Kerajinan Dari Barang Bekas di Desa Bahari" pertama-tama dilakukan persiapan pembelajaran sesuai dengan rencana dan jadwal kegiatan yang dituangkan dalam acuan pelaksanaan. Kegiatan kedua yaitu sosialisasi dan koordinasi pelaksanaan kegiatan. Setelah itu Pelaksanaan Pembelajaran, untuk pelaksanaan pembelajaran peserta kegiatan Pemberdayaan Masyarakat Melalui Pelatihan Pembuatan Kerajinan dari Barang Bekas di Desa Bahari adalah perempuan berusia 15-59 tahun. Setelah itu penyelenggaraan bersama Tim PKM dan peserta, membuat kesepakatan (kontrak belajar). Kontrak belajar mencakup jadwal, tempat, waktu, dan tata tertib.

Setelah itu melaksanakan kegiatan pembelajaran/keterampilan dasar usaha. Kegiatan tersebut dilakukan secara terstruktur yaitu mengungkapkan keinginan berusaha 
berdasarkan minat dan potensi yang tersedia; mempraktikkan sebuah keterampilan yang berpeluang menjadi bidang usaha sesuai minat dan potensi yang dimiliki. Pelaksaanaan pembelajaran dilakukan dengan pelatihan dan pendampingan keterampilan pembuatan kerajinan dari barang bekas. Pendampingan yang diberikan tim PKM yaitu bagaimana cara membuat kerajinan menggunakan bahan barang bekas, cara pemasaran yang baik dan benar, metode yang diberikan dalam pelatihan secara demontrasi.

Dalam materi pelatihan cara membuat kerajinan dari barang bekas ibu-ibu diberikan pembelajaran terlebih dahulu bagaimana cara memilih bahan yang bagus untuk dibuat menjadi sebuah kerajinan, selain itu ibu-ibu diajarkan bagaimana mengelola bahan tersebut agar bisa menjadi sebuah karya yang nantinya memiliki harga jual. Tim PKM melakukan pelatihan secara demonstrasi, setelah memberikan pengarahan tim PKM langsung mempraktikan kepada peserta pelatihan cara membuat kerajina menggunakan barang bekas

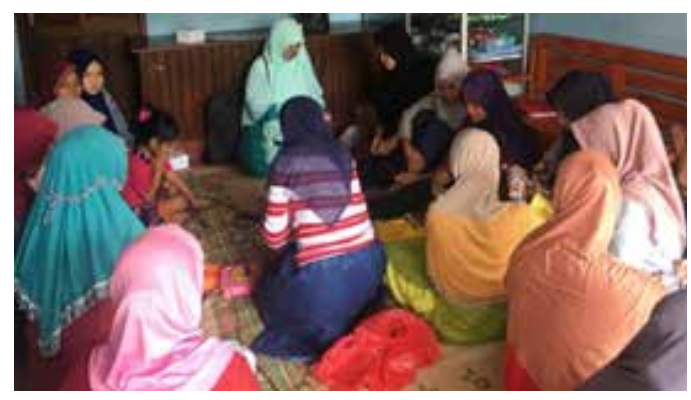

Gambar 2. Pelatihan dan Pendampingan Pembuatan Kerajinan

Dari beberapa kali pelatihan dan pendampingan, mulai dari pengenalan alatalat yang digunakan untuk membuat kerajinan membuat peserta pemberdayaan masyarakat mengerti atau paham kegunaan alat tersebut. Kemudian melatih mereka dengan membuat kerajinan yang sederhana terlebih dahulu hingga membuat kerajinan yang membutuhkan konsentrasi tinggi.

Hasil pelatihan pemberdayaan masyarakat dengan menggunakan barang bekas membuat penduduk desa memiliki keterampilan dalam mengolah sampah plastik dan botol bekas sehingga memiliki nilai yang lebih ekonomis. Selain itu masyarakat memiliki kreativitas yang tinggi dalam menciptakan produk yang lebih variatif.

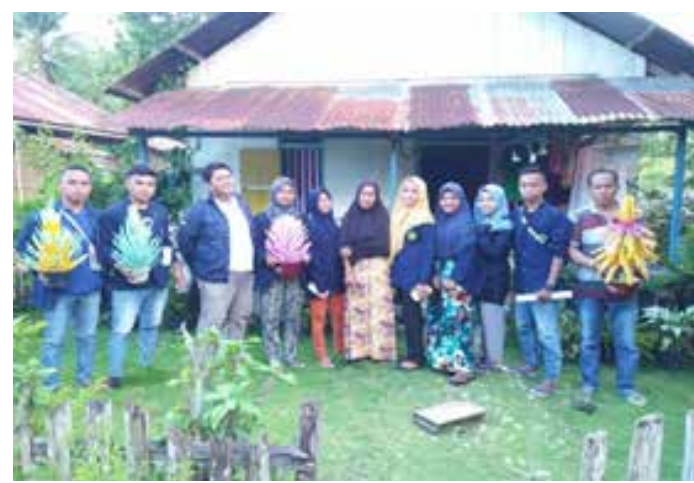

Gambar 3. Hasil Kerajinan peserta

Pemberdayaan Masyarakat Melalui Pelatihan Pembuatan Kerajinan Dari Barang Bekas.

Selain adanya perubahan sosial dan peningkatan perekonomian dengan adanya Pemberdayaan Masyarakat Melalui Pelatihan Pembuatan Kerajinan dari Barang Bekas, ibuibu ini juga banyak mendapatkan pengetahuan bagaimana cara pembuatan kerajinan, bagaimana sistem pemasaran yang baik dan benar, bahan-bahan apa saja yang digunakan dalam pembuatan kerajinan, dan juga ibu-ibu bisa mengetahui apa saja hambatan yang dapat menghambat proses pembuatan dan pemasaran. 


\section{KESIMPULAN}

Masyarakat yang mengikuti kegiatan pemberdayaan melalui pelatihan pembuatan kerajinan dari barang bekas di Desa Bahari memiliki keterampilan dalam mengolah sampah plastik dan botol bekas sehingga memiliki nilai yang lebih ekonomis. Selain itu peserta pemberdayaan memiliki kreativitas yang tinggi dalam menciptakan produk yang lebih variatif.

Dengan diberikan pelatihan untuk memasarkan produk kerajinan, peserta kegiatan pemberdayaan masyarakat akan mampu mempromosikan sendiri hasil kerajinan. Peserta juga dibekali untuk memperbaiki produk kerajinan dengan melihat kebutuhan konsumen dan mampu membuat hal yang baru dengan media plastik dan botol bekas.

\section{DAFTAR PUSTAKA}

Aziz, H. M. A. (Ed.). (2005). Dakwah pemberdayaan masyarakat: paradigma aksi metodologi. PUSTAKA PESANTREN.

Hidayat, S., Djumena, I., \& Darmawan, D. (2018). Pemberdayaan Perempuan Berbasis Ekonomi Kreatif melalui Pelatihan Pembuatan Keset dari Limbah Kain. Journal of Nonformal Education and Community Empowerment, 2(1), 20-30. https://doi.org/10.15294/pls. v2i1.23385 